\title{
EVALUASI PROSES MANAJEMEN SISTEM PADA USAHA PERCETAKAN DI KOTA SEMARANG
}

\author{
Faiqi Nabil ${ }^{1)}$, Hendra Praditya Ferdiansyah' ${ }^{2)}$, Ahmad Taufiq Harahap ${ }^{2)}$ \\ ${ }^{1,2,3}$ Program Studi Sistem Informasi, Universitas Negeri Semarang, J1. Sekaran Kota Semarang \\ E-mail: faiqinabil@students.unnes.ac.id ${ }^{1)}$, hendrapradityaf@students.unnes.ac.id ${ }^{2)}$, \\ ahmadtaufiq@students.unnes.ac.id ${ }^{3)}$
}

\begin{abstract}
Abstrak
Pencetakan adalah teknik industri untuk memproduksi teks dan gambar secara massal, terutama di atas kertas, dengan menggunakan tinta dan mesin cetak. Salah satu bisnis yang menggunakan proses pencetakan ialah perusahaan percetakan, usaha percetakan memiliki potensi pasar tinggi di Kota Semarang. Hal ini terlihat pada keuangan salah satu perusahaan percetakan di Semarang yang dinilai baik karena pendapatan tahunannya meningkat dibandingkan lima tahun sebelumnya. Di sisi lain, pendapatan percetakan turun pada tahun 2019 dibandingkan 2018. Penurunan ini terjadi akibat kinerjanya yang buruk, serta tantangan dan keterbatasan dalam operasional bisnisnya. Oleh karena itu, perlu mengkaji ulang dengan menganalisis kekurangan pada proses bisnisnya, mengidentifikasi proses seleksinya, dan mengukur kinerja proses dengan menilai seberapa baik kemajuan pekerjaan dalam kaitannya dengan tujuan dan sasaran yang telah ditentukan. Hasil dari analisis tersebut menunjukkan bahwa proses promosi pada perusahaan tersebut harus diperbarui dan ditingkatkan segera. Solusi untuk untuk meningkatkan kinerja proses promosi adalah dengan melakukan pemasaran online, seperti promosi dengan media sosial, e-commerce, dan mengembangkan situs web.
\end{abstract}

Kata kunci: Analisis Proses Bisnis, E-Commerce, E-Business, Percetakan, Pemasaran

\begin{abstract}
Printing is an industrial technique for mass-producing text and images, especially on paper, using ink and a printing press. One of the businesses that use the printing process is a printing company, the printing business has a high market potential in the city of Semarang. This can be seen in the finances of a printing company in Semarang, which is considered good because its annual income has increased compared to the previous five years. On the other hand, printing revenue fell in 2019 compared to 2018. This decline was due to its poor performance, as well as challenges and limitations in its business operations. Therefore, it is necessary to review it by analyzing deficiencies in its business processes, identifying the selection process, and measuring process performance by assessing how well the work is progressing in relation to the goals and objectives that have been determined. The results of the analysis indicate that the promotion process in the company must be updated and improved immediately. The solution to improve the performance of the promotion process is to do online marketing, such as promotion with social media, e-commerce, and developing a website.
\end{abstract}

Keywords: Business Process Analysis, E-Commerce, E-Business, Printing, Marketing

\section{PENDAHULUAN}

\subsection{Latar Belakang}

Pencetakan adalah teknik industri untuk memproduksi teks dan gambar secara massal, terutama di atas kertas, dengan menggunakan tinta dan mesin cetak [1].
Materi cetak dihasilkan dalam miliaran setiap hari. Mulai dari surat, spanduk, stiker, dan bahan lainnya. Ini karena hasil cetakan memungkinkan jutaan orang dengan cepat berbagi pendapat dan pengetahuan mereka. 
Berbagai operasi proses bisnis dilakukan pada perusahaan percetakan. Proses bisnis adalah sekumpulan aktivitas atau aktivitas yang saling berhubungan yang digunakan untuk memecahkan masalah atau menciptakan produk atau layanan [2]. Menurut Davenport (1993), proses bisnis didefinisikan sebagai operasi terukur yang menciptakan hasil spesifik untuk klien tertentu [3]. Sedangkan menurut Susanne Leist (2011), mendefinisikan proses bisnis sebagai serangkaian operasi yang menambah nilai input dan mengubahnya menjadi output [4].

Potensi pasar salah satu perusahaan percetakan di Semarang cukup menjanjikan. Hal ini terlihat pada keuangan mereka yang dinilai baik karena pendapatan tahunannya meningkat dibandingkan lima tahun sebelumnya. Di sisi lain, pendapatan percetakan turun pada tahun 2019 dibandingkan 2018. Penurunan ini terjadi akibat kinerjanya yang buruk, serta tantangan dan keterbatasan dalam operasional bisnisnya.

Sebuah analisis proses bisnis diperlukan oleh perusahaan tersebut untuk dapat mengidentifikasi dan menentukan area yang mungkin berubah untuk meningkatkan kinerja proses bisnisnya. Analisis proses bisnis menurut Vergidis (2007) adalah sebuah kata yang mencakup berbagai teknik termasuk sebagai simulasi dan diagnostik, verifikasi, dan analisis kinerja proses bisnis [5]. Dengan perbaikan sistem dan proses bisnis suatu perusahaan akan memperoleh manfaat maksimal diantaranya mendapatkan keberlanjutan yang lebih baik [6]. Penambahan tool maupun alat dalam implementasi analisis proses bisnis juga akan membuat sebuat bisnis berjalan lebih baik [7]. Hal-hal tersebut akan merubah motivasi pengguna untuk lebih semangat dalam mengaplikasikan sistem dan perubahan atas analisis proses bisnis yang dilakukan [8].
Tujuan dari penelitian ini adalah untuk mengkaji proses bisnis perusahaan tersebut sehingga mengetahui kesulitan dan batasan apa yang mungkin timbul. Menurut Gunasekaran dan Kobu, (2002) proses bisnis didefinisikan sebagai sekelompok hubungan bisnis yang memberikan nilai bagi konsumen ketika disatukan [9]. Definisi lain proses bisnis menurut Wikipedia adalah serangkaian kegiatan atau upaya yang saling berhubungan secara sistematis yang ditujukan untuk memecahkan masalah tertentu atau menghasilkan produk atau layanan tertentu (untuk mencapai tujuan tertentu) [10].

Tujuan lainnya adalah untuk menentukan ukuran kinerja proses perusahaan tersebut, mengidentifikasi proses seleksi, dan memberikan solusi masalah yang tepat guna meningkatkan pendapatan proses bisnis percetakan perusahaan tersebut.

\section{METODE PENELITIAN}

\subsection{Objek Penelitian}

Menurut Sugiyono (2014) objek penelitian merupakan karakteristik, sifat, atau nilai seseorang, benda, atau kegiatan yang memiliki variasi yang ditetapkan oleh peneliti untuk diteliti dan ditarik kesimpulannya [11]. Artikel ini menggunakan objek penelitian berupa perusahaan yang beralamat Kota Semarang.

\subsection{Metode Pengumpulan Data}

Dalam mengumpulkan data, kami menggunakan metode observasi. Menurut Riyanto (2010), Observasi merupakan metode pengumpulan data yang mengandalkan pengamatan langsung dan tidak langsung [12]. Pengamatan kami dilakukan secara tidak langsung terhadap objek penelitian.

\subsection{Metode Analisis Data}

\subsection{Tujuan}


Metode analisis data merupakan tahapan proses penelitian dimana data yang telah terkumpul dikelola untuk diolah guna memecahkan masalah yang telah diidentifikasi [13]. Berikut adalah metode menganalisis data yang kami gunakan:

\subsection{Identidikasi Proses Bisnis}

Urutan operasi yang bertujuan untuk secara menyeluruh mendefinisikan kumpulan proses bisnis perusahaan dan menetapkan kriteria eksplisit untuk memeringkatnya dikenal sebagai identifikasi proses bisnis [14].

\subsection{Identifikasi Proses Seleksi}

Tujuan dari Process selection adalah untuk memberikan kriteria dalam mengevaluasi kinerja proses bisnis yang telah diidentifikasi. Proses ini didasarkan pada gagasan bahwa proses bisnis bervariasi dalam relevansi dan kesempurnaanya. Pengukuran performa proses kinerja harus dievaluasi bersama dengan sebuah kriteria untuk menetapkan dasar yang kuat dalam pemilihan proses (Process selection). Keuntungan adanya pengukuran proses kinerja, nantinya hasil dari pengukuran tersebut dapat digunakan untuk mengalokasikan sebuah kumpulan proses menjadi portofolio proses.

Tidak semua proses mempunyai kepentingan yang sama, dan tidak semua proses mampu menerima perhatian yang sama. Komitmen, kepemilikan, dan investasi dalam peningkatan kinerja dan desain ulang adalah bagian dari BPM. Akibatnya, prosedur yang menyebabkan kerugian atau risiko harus diperiksa untuk konsolidasi, penonaktifan, atau penghapusan/eliminasi lengkap. Untuk memandu tinjauan ini, sejumlah kriteria telah ditawarkan [15]. Berikut ini adalah kriteria-kriteria yang paling umum untuk digunakan:
1. Kepentingan strategis, kriteria ini berfokus pada proses evaluasi signifikansi strategis pada setiap proses. Tujuannya adalah untuk menentukan proses mana yang paling berpengaruh pada tujuan strategis organisasi. Jika dinyatakan secara tegas, strategi diartikan sebagai awal dari keberhasilan dalam menghadapi dinamika perusahaan agar para pelaku bisnis dapat berkembang di dalamnya [16].

2. Kesehatan, kriteria ini berusaha memberikan penilaian tingkat tinggi dari kesehatan pada setiap proses. Tujuan dari kriteria ini adalah untuk mengetahui proses mana yang berada dalam permasalahan yang paling serius.

3. Kualitas, secara umum upaya BPM harus berkonsentrasi pada proses-proses realistis yang layak digunakan untuk memperoleh keuntungan.

\subsection{Pengukuran Kinerja Proses}

Pengukuran kinerja adalah proses menilai seberapa baik kemajuan pekerjaan dalam kaitannya dengan tujuan dan sasaran yang telah ditentukan, termasuk data tentang: efisiensi sumber daya dalam memproduksi barang dan jasa; kualitas barang dan jasa (seberapa baik barang dan jasa disampaikan kepada pelanggan dan seberapa puas mereka); dan efektivitas kegiatan dalam mencapai tujuan [17]. Pengamatan ini mengarah untuk mengidentifikasi dimensi keempat proses kinerja, yaitu:

1. Waktu, indikator yang dibutuhkan untuk memproses suatu kasus dari awal sampai akhir.

2. Biaya, biaya disini dapat ditekankan pada perputaran, keuntungan atau penjualan. Tentunya, meningkatnya hasil pendapatan dapat memiliki efek yang sama pada pendapatan organisasi dengan mengurangi biaya

3. Kualitas, kualitas proses bisnis dapat dilihat dari setidaknya dua perspektif yang berbeda, yaitu perspektif 
pelanggan dan dari perspektif mereka yang terlibat dalam proses.

4. Fleksibilitas, merupakan faktor yang jarang disertakan saat mengevaluasi dampak perubahan proses. Kemampuan untuk menyesuaikan diri dengan perubahan adalah definisi yang luas dari fleksibilitas. Cara lain untuk melihat komponen kinerja fleksibilitas adalah dengan membedakan antara fleksibilitas run-time dan build-time. Kapasitas untuk mengelola modifikasi dan variasi selama pelaksanaan proses bisnis tertentu disebut sebagai fleksibilitas runtime. Build time Kapasitas untuk memodifikasi struktur proses bisnis disebut sebagai waktu fleksibilitas. Akibatnya, sangat penting untuk membedakan fleksibilitas dari aspek lain dari operasi bisnis.

\section{HASIL DAN PEMBAHASAN}

\subsection{Indentifikasi Proses Bisnis}

Proses bisnis adalah serangkaian operasi berulang yang terhubung secara logis yang menggunakan sumber daya perusahaan untuk memproses item fisik atau mental untuk menghasilkan produk atau hasil yang dapat diukur dan ditentukan sebelumnya untuk klien internal atau eksternal [18]. Kami dapat mengidentifikasi proses bisnis di salah satu perusahaan percetakan di Semarang sebagai berikut berdasarkan definisi diatas:

\section{Pengadaan bahan baku}

Pengadaan bahan baku merupakan salah satu langkah pra produksi industri percetakan. Karena zat ini merupakan komponen yang diperlukan dalam proses pembuatannya. Kertas, tinta cetak, berbagai jenis rol, perekat, plastik, benang, kawat, dan bahan baku lainnya.

2. Produksi

Terdapat tiga tahapan dalam proses produksi pada perusahaan percetakan di Kota Semarang, yaitu:

a. Pra-cetak, dimulai dengan entri data dan diakhiri dengan desain siap cetak, ini adalah proses pengembangan desain cetak dengan perangkat komputer

b. Cetak, merupakan proses utama dari sebuah perusahaan percetakan, dan bertanggung jawab untuk mencetak sesuatu di atas kanvas/bahan tertentu yang telah disepakati oleh pelanggan

c. Pasca-cetak, Finishing dan pengepakan adalah dua tugas yang membentuk proses pasca-cetak. Setelah media dicetak menjadi produk cetak yang siap diberikan kepada klien, finishing merupakan prosedur yang harus dilakukan di perusahaan percetakan [19]. Pengepakan adalah sistem yang mengoordinasikan persiapan barang untuk transit, distribusi, penyimpanan, penjualan, dan penggunaan [20].

\section{Pengiriman}

Setelah proses pengepakan, produk diidentifikasi dan jumlahnya dicatat untuk menyiapkan dokumen pengiriman nanti. Barang dikirim sesuai dengan batas waktu pengiriman yang dipilih pelanggan.

4. Pemasaran

Menawarkan jasa percetakan kepada masyarakat umum merupakan salah satu bentuk promosi. Perusahaan tersebut mempromosikan dirinya menggunakan metode kuno dari iklan mulut ke mulut. Selanjutnya, melalui penggunaan pamflet dan iklan surat kabar.

5. Pelayanan pelanggan

Pelanggan memesan antara lain dalam bentuk file desain, bahan, dan ukuran. Konsumen tetap dapat memperoleh informasi mengenai jaminan cetak, jaminan pembayaran, dan hal-hal lain setelah prosedur transaksi bisnis selesai. Jika hasil cetak rusak atau cacat, dapat dikembalikan dan ditukar dengan yang baru. 


\subsection{Identifikasi Proses Seleksi}

Tujuan utama perusahaan tersebut adalah untuk mendapatkan keuntungan/profitabilitas dari barang dan jasa yang dijual. Karena pendapatannya menurun pada 2019 dibandingkan 2018, namun biaya promosi meningkat, dapat dikatakan bahwa proses promosi perusahaan tidak berjalan sebagaimana mestinya.

Tabel 1. Proses Seleksi

\begin{tabular}{c|ccc}
\hline Proses & Kepentingan & Kesehatan & Kelayakan \\
\hline Pengadaan & $95 \%$ & $90 \%$ & $70 \%$ \\
\hline Produksi & $95 \%$ & $75 \%$ & $50 \%$ \\
\hline Pengiriman & $80 \%$ & $90 \%$ & $70 \%$ \\
\hline Pemasayan & $95 \%$ & $35 \%$ & $40 \%$ \\
\hline Pelayanan & $90 \%$ & $85 \%$ & $80 \%$ \\
\hline
\end{tabular}

\subsection{Pengukuran Kinerja Proses}

Penilaian kinerja proses, sebagaimana dinyatakan dalam teknik analisis data, adalah proses menilai seberapa baik kemajuan pekerjaan dalam kaitannya dengan tujuan dan sasaran yang ditentukan. Proses bisnis pemasaran adalah sesuatu yang harus difokuskan, berdasarkan latar belakang dan identifikasi proses seleksi. Kami berkonsentrasi pada evaluasi efektivitas prosedur ini dalam kaitannya dengan proses pemasaran.

1. Waktu

Pendistribusian brosur membutuhkan waktu yang lama dalam proses periklanannya (sebulan sekali). Sedangkan proses yang lain membutuhkan perputaran waktu yang cepat (harian/mingguan).

2. Biaya

Pencetakan pamflet dan iklan surat kabar merupakan bagian mahal dari proses promosi. Sedangkan proses lain membutuhkan biaya yang cukup sesuai dengan apa yang dihasilkan.

3. Kualitas

Di era digital ini, metode promosi yang dilakukan perusahaan tersebut berkualitas buruk dan sangat kuno. Pada proses yang lain cenderung memiliki kualitas yang baik dan disenangi oleh pelanggan.

4. Fleksibilitas

Metode promosi yang menggunakan media seperti brosur tidak efisien karena tidak dapat menjangkau sebanyak mungkin orang, dan membutuhkan lebih banyak energi untuk mendistribusikannya, sehingga menimbulkan anggaran baru.

\subsection{Matrix Portofolio Proses}

Importance-Performance Matrix merupakan strategi yang biasa digunakan untuk mengidentifikasi faktor-faktor layanan yang memiliki dampak signifikan terhadap kebahagiaan dan loyalitas pelanggan, serta variabel layanan yang perlu ditingkatkan karena persepsi konsumen terhadap barang perusahaan berbeda [21].

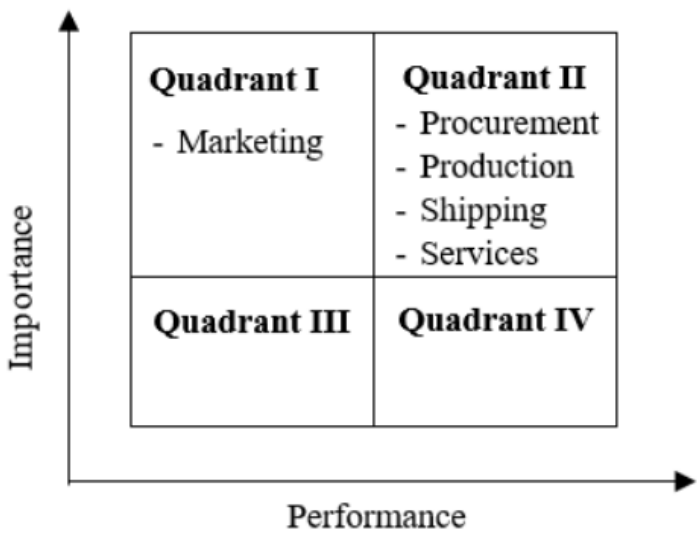

Gambar 1. Matriks Portofolio Proses

Kuadran I adalah daerah yang memiliki kepentingan yang tinggi tetapi kinerjanya lemah, daerah ini sangat amat dipriotiaskan untuk perbaikan proses. Kuadran II adalah daerah yang memiliki kepentingan tinggi dan kinerja yang tinggi, 
proses yang menempati kuadran ini tidak perlu perbaikan. Kuadran III adalah daerah yang memiliki kepentingan rendah dan kinerja rendah, kuadran ini tidak memiliki prioritas. Kuadran IV adalah daerah yang memiliki kepentingan rendah dan kinerja yang maksimal

\subsection{Abstraksi BPM}

Abstraksi BPM adalah generalisasi yang menghilangkan detail yang tidak perlu, hanya menyisakan detail paling kritis tentang suatu item atau fenomena. Abstraksi dicapai dengan menggeneralisasi bagian-bagian model yang tidak signifikan. Abstraksi model proses digunakan untuk mencari tahu untuk apa model proses digunakan. Untuk membuat maksud dan tujuan suatu prosedur lebih mudah dipahami [22]. Tujuan pemodelan di bawah adalah untuk mengetahui proses bisnis yang dilakukan oleh salah satu perusahaan percetakan di Semarang, sehingga dapat mempermudah dalam menganalisis aktivitas yang memiliki kekurangan.

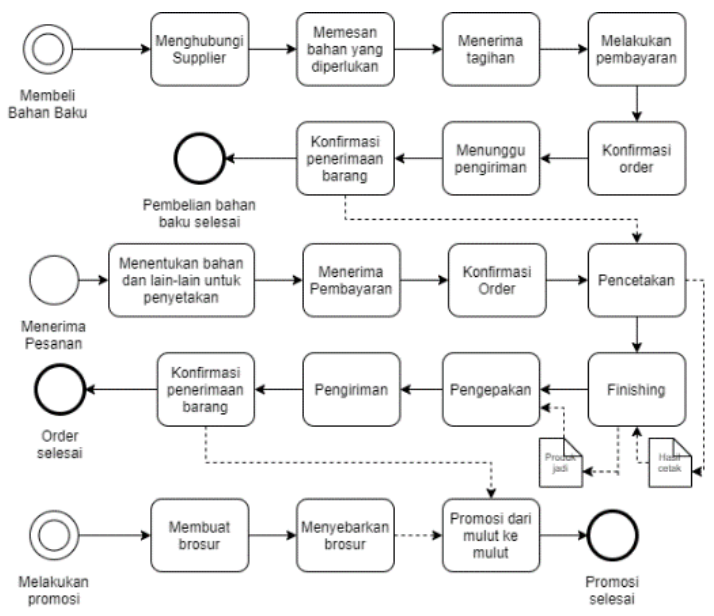

Gambar 2. Abstraksi BPM Perusahaan Percetakan di Semarang

\section{KESIMPULAN DAN SARAN}

Berdasarkan hasil analisis proses bisnis yang dilakukan pada salah satu perusahaan percetakan di Semarang, dapat disimpulkan bahwa ada lima jenis proses bisnis, yaitu: pengadaan bahan baku, produksi, pengiriman, pemasaran, dan pelayanan pelanggan. Masalah dengan pendekatan bisnis perusahaan percetakan tersebut adalah bahwa promosi masih di bawah standar (hanya dari mulut ke mulut, melalui brosur dan iklan di koran, dan membutuhkan banyak uang \& tenaga).

Untuk meningkatkan kinerjanya, perusahaan tersebut dapat mempertimbangkan untuk melakukan pemasaran internet, seperti menjalankan promosi menarik di media sosial. Media sosial adalah jenis media elektronik yang digunakan untuk menghubungkan orang atau untuk membangun ruang digital di mana orang dapat bertukar pesan dan terlibat [23].

Kemudian, cara yang berikutnya adalah dengan menggunakan iklan media virtual untuk meningkatkan efisiensi dan efektivitas pemasaran, menyiapkan etalase pada marketplace, dan mengembangkan situs web yang dapat diakses pelanggan dengan mudah.

\section{DAFTAR PUSTAKA}

[1] "Percetakan," Wikipedia bahasa Indonesia, ensiklopedia bebas. https://id.wikipedia.org/wiki/Perceta kan (accessed Dec. 02, 2021).

[2] Widayanto, "Analisis Proses Bisnis Usaha Mikro Kecil Menengah (Umkm) Konveksi Ryan Collection Di Kabupatan Kudus," Univ. Diponegoro, 2017.

[3] T. Davenport, "Process Innovation: Reengineering work through information technology," Harvard Bus. Sch. Press. Bost., 1993.

[4] S. Leist, "A Systematic Approach for the Improvement of Business Processes based on Techniques and Patterns," ERCIS, 2011.

[5] V. Kostas, "Business Process Analysis and Optimization: Beyond Reengineering," IEEE Trans. Syst. Man, Cybern. -Part C Appl. Rev., 2007.

[6] K. Budiman, S. Subhan and D. 
Efrilianda, "Business Process reengineering to support the sustainability of the construction industry and sales commodities in large scale transaction during Covid 19 with integrating ERP and Quotation System", Scientific Journal of Informatics, vol. 8, no. 1, pp. 84-91, 2021, doi: 10.15294/sji.v8i1.27969.

[7] O. Khoirunnisa, D. A. A. Pertiwi, E. N. Dianti, A. M. M. Fattah, and K. Budiman, "Improvement business process model and notation on the drink distribution industries using six core element", JOSCEX, vol. 2, no. 2, pp. 99-106, Sep. 2021, doi: 10.52465/joscex.v2i2.46.

[8] K. Budiman and I. Akhlis, "Changing user needs and motivation to visit a website through ad experience: a case study of a university website", Journal of Physics: Conference Series, vol. 1918, no. 4, p. 042008, 2021, doi: 10.1088/17426596/1918/4/042008.

[9] A. and B. K. Gunasekaran, "Modelling and Analysis of Business Process Reengineering," Int. j. prod. res., 2002, vol. 40, no. 11, 2521-2546, 2002.

[10] "Proses bisnis," Wikipedia bahasa Indonesia, ensiklopedia bebas. https://id.wikipedia.org/wiki/Proses_ bisnis (accessed Dec. 02, 2021).

[11] R. Karim, "Pengertian Objek Penelitian: Jenis, Prinsip dan Cara Menentukan,"

penerbitbukudeepublish.com, 2021. https://penerbitbukudeepublish.com/ pengertian-objek-penelitian/ (accessed Dec. 02, 2021).

[12] Syafanidawaty, "Observasi," Univeritas Raharja, 2020. https://raharja.ac.id/2020/11/10/obse rvasi/ (accessed Dec. 02, 2021).

[13] S. M. Rezkia, "Macam-Macam Metode Analisis Data: 2 Macam Metode Penting dalam Mengolah Data," dqlab.id, 2021. https://www.dqlab.id/macammacam-metode-analisis-data-2macam-metode-penting-dalammengolah-data\#: :text=Metode analisis data merupakan bagian,menghasilkan kesimpulan dalam pengambilan keputusan (accessed Dec. 02, 2021).

[14] "Process Identification," Univ. Syarif Hidayatullah Jakarta, 2020.

[15] H. A. R. Marlon Dumas, Marcello La Rosa Jan Mendling, Fundamentals of Business Process Management, II. 2017.

[16] E. Kurniawan and I. Irwansyah, "Analisis Strategi Pemasaran Pada Media Sosial Melalui Iklan Instagram", Jurnal Teknologi Dan Sistem Informasi Bisnis, vol. 3, no. 2, pp. 294-307, 2021, doi: https://doi.org/10.47233/jteksis.v3i2. 247.

[17] T. K. Abraham, "Strategic planning," An Integr. Approach to New Food Prod. Dev., no. 1991, pp. 27-36, 2009

doi: $10.1177 / 1028315312464655$.

[18] U. Danny, "Materi Analisa Proses Bisnis," [Online]. Available: http://umardanny.com/materianalisa-proses-bisnis-ppt/.

[19] C. Wiranata, "Penjelasan 10 Jenis Finishing Percetakan Offset dan Digital," solusiprinting.com, 2019. Penjelasan 10 Jenis Finishing Percetakan Offset dan Digital (accessed Dec. 02, 2021).

[20] "Pengemasan," Wikipedia bahasa Indonesia, ensiklopedia bebas. https://id.wikipedia.org/wiki/Pengem asan (accessed Dec. 02, 2021).

[21] R. Utami and S. Atmojo, "Implementasi Metode ImportancePerformance Matrix Untuk Evaluasi Dan Peningkatan Pelayanan Jasa Care Cleaners," Kinet. Game Technol. Inf. Syst. Comput. Network, Comput. Electron. Control, vol. 2, no. 3, pp. 235-242, 2017, doi: 10.22219/kinetik.v2i3.176. 
DOI : https://doi.org/10.47233/jteksis.v4i1.343

[22] M. Singadji, "Business Model Abstraction," Univ. Pembang. Jaya, 2013.

[23] A. Rahmadhany and I. Irwansyah, "Pemanfaatan Media Sosial Instagram Sebagai Strategi Komunikasi Informasi Pemasaran Produk", Jurnal Teknologi Dan Sistem Informasi Bisnis, vol. 3, no. 2, pp. 320-326, 2021, doi: 10.47233/jteksis.v3i2.250. 